$\overline{\text { SHORT COMMUNICATIONS }}$

Proc. Estonian Acad. Sci. Biol. Ecol., 2002, 51, 3, 217-221

\title{
Recent distribution of Aglaothamnion roseum (Rhodophyta) in Estonian coastal waters, NE Baltic Sea
}

\author{
Kaire Torn and Helen Orav \\ Estonian Marine Institute, University of Tartu, Marja 4d, 10617 Tallinn, Estonia; kairet@klab.envir.ee \\ Received 22 October 2001, in revised form 10 January 2002

\begin{abstract}
Macrophytobenthos was studied in the Estonian coastal sea. An overview about the historical distribution data of a rare red alga Aglaothamnium roseum is given. In recent years A. roseum was found at three different sites in the southern coastal sea of Saaremaa Island - near the Kaugatuma Cliff, in Kuressaare Bay, and at two different sites of Kõiguste Bay.
\end{abstract}

Key words: Aglaothamnion, Baltic Sea, distribution, macrophytobenthos.

\section{INTRODUCTION}

A total of 159 species of red algae (Rhodophyta) have been found from the Baltic Sea. The genus Aglaothamnion (previously Callithamnion) is represented by five species: A. bipinnatum, A. byssoïdes, A. gallicum, A. hookeri, and A. roseum. A. bipinnatum is found only in the Kattegat and the Belt Sea area and A. hookeri is found in the Kattegat, the Belt Sea area, and Kiel Bay. The distribution of A. byssoïdes in the Baltic Sea is limited to the Western Gotland Basin. The most frequent species of this genus is A. roseum, which is found all over the sea area except Bornholm and Gdansk basins (Nielsen et al., 1995). In Estonian coastal waters only A. roseum is found (Trei, 1991; Nielsen et al., 1995). The species has been more frequently found in the Väinameri (Trei, 1991).

As its frequency is low, A. roseum is not very well described in the Estonian coastal sea in terms of its distribution and ecological requirements. As the latest published information about this species is available only from the late 1980s the 
aim of the present work was to give an overview of the recent distribution of A. roseum and relate it to environmental conditions.

\section{MATERIAL AND METHODS}

The bottom vegetation was studied at the southern coast of the Gulf of Finland, in the Väinameri area, in the Gulf of Riga, and in coastal areas of the Baltic Proper (Fig. 1).

A total of 611 samples were collected in 22 different areas from 1995 to 2000. Three replicate samples $(20 \times 20 \mathrm{~cm})$ were randomly taken on each site for phytobenthos determination. Samples below $0.5 \mathrm{~m}$ were taken by SCUBA diving. Sampling was done once a year from July to September. Samples were kept in a deep freezer $\left(-20^{\circ} \mathrm{C}\right)$. In the laboratory the samples were sorted, species were determined, and dry weights $\left(2\right.$ weeks at $\left.60^{\circ} \mathrm{C}\right)$ of each species were measured.

Data of the Estonian National Marine Monitoring Programme were used to relate the distribution of macroalgae to the environmental conditions. The values of salinity and tot- $\mathrm{N}$ and tot-P in March were averaged over the period of 19952000. The station at $57^{\circ} 58^{\prime} \mathrm{N}$ latitude and $21^{\circ} 33^{\prime} \mathrm{E}$ longitude was considered to represent the Kaugatuma site, the stations at $57^{\circ} 50^{\prime} \mathrm{N}, 22^{\circ} 17^{\prime} \mathrm{E}$ and $57^{\circ} 49^{\prime} \mathrm{N}$, $22^{\circ} 53^{\prime}$ E represented Kõiguste Bay, and $57^{\circ} 12^{\prime}$ N, $23^{\circ} 24^{\prime}$ E Kuressaare Bay.

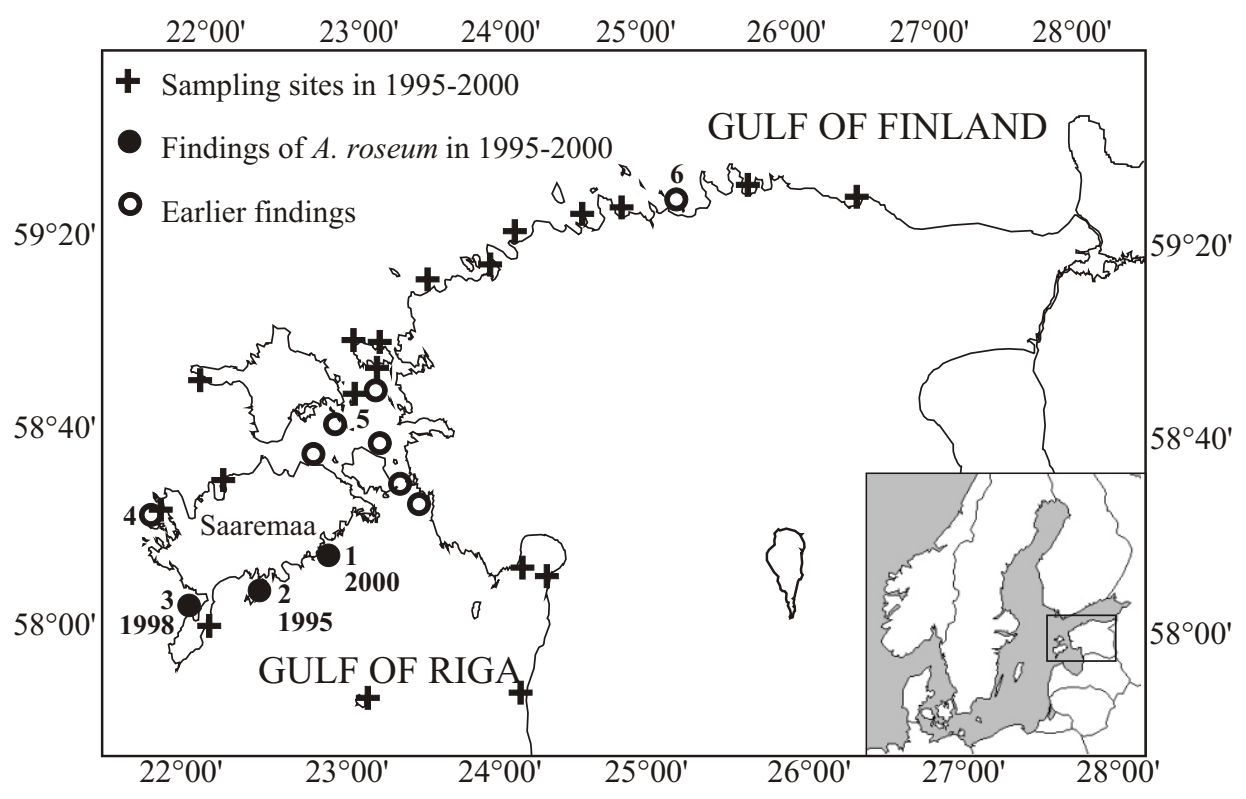

Fig. 1. Location of macrobenthic study sites in 1995-2000 together with the findings of Aglaothamnion roseum in Estonian waters (Trei, 1976; Kukk, 1979, 1988). 1, Kõiguste Bay; 2, Kuressaare Bay; 3, Kaugatuma Cliff; 4, Vilsandi Island; 5, Väinameri; 6, Kolga Bay. 


\section{RESULTS AND DISCUSSION}

In the Baltic Sea the marine species A. roseum is a quite common but not a very frequent species up to the Danish Belts and adjacent bays (Lakowitz, 1929; Kolderup Rosenvinge, 1935; Nielsen et al., 1995). From the eastern part of the Baltic Sea this species has been observed only a couple of times (Trei, 1975, 1976). The northernmost Baltic records were previously connected to the Öregrund Archipelago in Sweden and the Tvärminne Archipelago in Finland (Waern, 1952; Ravanko, 1968; Hällfors et al., 1981). The northern distribution limit of the species in the sea areas is between the Bothnian Sea and Bothnian Bay (Bergström \& Bergström, 1999).

A. roseum was noted from the Aland Sea by Waern (1952) in the middle of the 20th century. During investigations in 1993 this species had disappeared or was not recorded in the eastern part of the Åland Sea (Rönnberg \& Mathiesen, 1998). At the beginning of the 20th century this species was also recorded from the southern part of the Gulf of Riga (Skuja, 1924) but in the late 1980s it was not found. The authors of this paper suggest that this is due to the increasing pollution load, which has exerted its largest influence on the macrophytes in the southern part of the Gulf of Riga (Kukk, 1993, 1995).

During this study A. roseum was found at three different sites in the southern coastal sea of Saaremaa Island (Fig. 1). The species was found in Kuressaare Bay during 1995, near the Kaugatuma Cliff in 1998, and at two different sites in Kõiguste Bay in 2000. The distance between the Kõiguste sites was approximately $1.5 \mathrm{~km}$. In the bays of Kaugatuma and Kõiguste A. roseum has not been recorded earlier (Trei, 1991; Kukk, 1993, 1995) whereas in the adjacent waters of Kuressaane Bay the species was reported in the late 1980s. The salinity in the sites where the species was found was 5.6-7.1 PSU, which corresponds to the previous observations of the salinity tolerance of this species (Trei, 1976; Kukk, 1979). The species comprised a minor part of the whole phytobenthic biomass. A. roseum occurred more frequently with the phaeophytes Sphacelaria arctica and Stictyosiphon tortilis and the rhodophytes Furcellaria lumbricalis and Polysiphonia fucoides.

In Estonia A. roseum was described for the first time by Trei (1976) from the Väinameri. In her material collected during a quarter of a century from Estonian coastal waters this species was represented only in the central and western parts of the Väinameri. All 12 findings came from areas with a salinity of 6.2-7.2 PSU, at depths of 4 to $11 \mathrm{~m}$. This species occurred in low abundance mostly as an epiphyte on other red and brown algae, mainly on S. arctica (Trei, 1976, 1991). In addition, this species has been recorded also from Kolga Bay (the Gulf of Finland), adjacent areas of Vilsandi Island, and the northern part of the Gulf of Riga (Kukk, 1979, 1988, 1993, 1995; Trei et al., 1987; Nielsen et al., 1995; Martin, 1999). In Kolga Bay the species was found in two localities on slightly sandy stony bottom at a depth of $14 \mathrm{~m}$. At these localities it was epiphytic on S. arctica. The salinity of the area was 5.5 PSU (Kukk, 1979). Close to Vilsandi Island the species was found only in one locality at a depth of $18 \mathrm{~m}$ as an epiphyte 
of Rhodomela confervoides (Kukk, 1988). A. roseum has been mentioned from the Gulf of Riga (Kukk, 1993, 1995; Martin, 1999) but in all cases the same single finding was described. The material was collected during 1986-91; however, the exact location of the species is not mentioned. Most likely A. roseum occurs around the entire Estonian coastline but due to its low frequency and small thallus it may be often missed during identification.

Very little is known of the tolerance of the species to pollution. We found $A$. roseum both at low nutrient concentrations near the Kaugatuma Cliff (tot-N $0.19 \pm 0.02 \mathrm{mg} / \mathrm{L}$, tot-P $0.022 \pm 0.003 \mathrm{mg} / \mathrm{L}$ ) and in moderately polluted Kuressaare and Kõiguste bays (tot-N $0.43 \pm 0.04 \mathrm{mg} / \mathrm{L}$, tot-P $0.046 \pm 0.002 \mathrm{mg} / \mathrm{L}$ ).

Earlier evidence on the tolerance of the species to pollution is controversial. Kolderup Rosenvinge (1923-24) found it from the highly polluted harbour of Fredrikshavn, indicating low sensitivity of the species to pollution. Later the species was recorded from both highly and less polluted localities in The Netherlands (Munda, 1967), and in a slightly eutrophicated locality (Lindgren, 1978). According to Hällfors et al. (1987) A. roseum prefers pristine areas of low nutrient concentration. The experiments with a related species, Aglaothamnion hookeri, demonstrated that an increased concentration of nitrates and phosphates had no effect on the growth of the alga (Edwards, 1972). According to Kukk (1995) the species most likely disappeared in the southern part of the Gulf of Riga due to the increasing pollution load. Most information on the environmental tolerance of the species is however circumstantial based on the distribution data of the species. Hence, relevant experiments are needed to validate the effect of pollution load on the species.

\section{ACKNOWLEDGEMENTS}

The fieldwork of this study was financed by the Estonian National Monitoring Programme funded by the Estonian Ministry of the Environment. This study was supported by the Estonian Governmental Programme No.0200792s98. Many thanks are due to Georg Martin and Jonne Kotta for their comments and critical reading of the manuscript.

\section{REFERENCES}

Bergström, L. \& Bergström, U. 1999. Species diversity and distribution of aquatic macrophytes in the Northern Quark, Baltic Sea. Nord. J. Bot., 19, 375-383.

Edwards, P. 1972. Cultured red alga to measure pollution. Mar. Poll. Bull., 3, 184-188.

Hällfors, G., Niemi, Å., Ackefors, H., Lassig, J. \& Leppäkoski, E. 1981. Biological oceanography. In The Baltic Sea (Voipio, A., ed.), pp. 219-274. Elsevier Oceanography Series, Amsterdam, 30.

Hällfors, G., Viitasalo, I. \& Niemi, A. 1987. Macrophyte vegetation and trophic status of the Gulf of Finland - a review of Finnish investigations. Meri. Inst. Mar. Res., Helsinki, 13, 111-158.

Kolderup Rosenvinge, L. 1923-24. The marine algae of Denmark. Mem. Acad. R. Sci. Lett. Danemark, Copenhague, 7 ser., VII(3), 287-490.

Kolderup Rosenvinge, L. 1935. Distribution of the Rhodophyceae in the Danish waters. Mem. Acad. R. Sci. Lett. Danemark, Copenhague, 9 ser., VI(2), 3-43. 
Kukk, H. 1979. Benthic vegetation of the Soviet coastal waters of the Gulf of Finland. Cand. Sci. dissertation.Tallinskoe otdelenie BaltNIIRH, Tallinn (in Russian).

Kukk, H. 1988. Benthic vegetation of the surroundings of Vilsandi Island. In Vilsandi Island as an Example of Egological Monitoring (Ratas, U. \& Nilson, E., eds.), pp. 93-100. Valgus, Tallinn (in Russian).

Kukk, H. 1993. Floristic composition of the phytobenthos and its long-term changes in the Gulf of Riga, the Baltic Sea. Proc. Estonian Acad. Sci. Ecol., 3, 85-91.

Kukk, H. 1995. Phytobenthos. In Ecosystem of the Gulf of Riga between 1920 and 1990 (Ojaveer, E., ed.), pp. 131-138. Estonian Academy Publishers, Tallinn.

Lakowitz, K. 1929. Die Algenflora des gesamten Ostsee. Kommissions-Verlag von R. Friedländer \& Sohn, Danzig.

Lindgren, L. 1978. Algzonering på klippiga stränder I Porkala, Helsingfors och Sibbo som bas för fortsatt kontroll av föroreningsläget. MSc thesis. University of Helsinki, Department of Botany.

Martin, G. 1999. Distribution of phytobenthos biomass in the Gulf of Riga (1984-1991). Hydrobiologia, 393, 181-190.

Munda, I. 1967. Changes in the algal vegetation of a part of the deltaic area in the southern Netherlands (Veerse Meer) after its closure. Bot. Mar., 10, 141-157.

Nielsen, R., Kristiansen, A., Mathiesen, L. \& Mathiesen, H. 1995. Distributional index of the benthic macroalgae of the Baltic Sea area. Acta Bot. Fenn., 155, 1-51.

Ravanko, O. 1968. Macroscopic green, brown, and red algae in the southwestern archipelago of Finland. Acta Bot. Fenn., 79, 1-50.

Rönnberg, O. \& Mathiesen, L. 1998. Long-term changes in the marine macroalgae of Lagskaer, Åland. Nord. J. Bot., 18, 379-384.

Skuja, H. 1924. Beitrag zur Algenflora des Rigaschen Meerbusens. Acta Univ. Latviensis, 10, 373392.

Trei, T. 1975. Flora and vegetation in the coastal waters of Western Estonia. Merentutkimuslait. Julk., 239, 348-351.

Trei, T. 1976. Brown and Red Algae of Western Estonia. Zvaigzne, Riga (in Russian).

Trei, T. 1991. Taimed Läänemere põhjal. Valgus, Tallinn.

Trei, T., Kukk, H. \& Kukk, E. 1987. Phytobenthos as an indicator of the degree of pollution in the Gulf of Finland and in neighbouring sea areas. Meri. Inst. Mar. Res., Helsinki, 13, 63-109.

Waern, M. 1952. Rocky-shore algae in the Öregrund Archipelago. Acta Phytogeogr. Suec., 30, 1-298.

\section{Punavetika Aglaothamnion roseum (Rhodophyta) viimased leiud Eesti vetes}

\section{Kaire Torn ja Helen Orav}

Aglaothamnium roseum on kogu Läänemeres hajusalt ja vähearvukalt esinev vetikaliik. Artiklis on antud ülevaade tema levikust Eesti rannikuvetes. 1995.2000. aastani koguti põhjataimestiku proove Soome lahe, Väinamere, Liivi lahe ja Läänemere avaosa rannikualadelt. Nende uuringute käigus leiti punavetikat A. roseum kolmes paigas Saaremaa rannikult - Kuressaare ja Kõiguste lahest ning Kaugatuma pangaga piirnevalt merealalt. Nendes piirkondades jäi soolsus vahemikku 5.6-7.1 PSU, toitainete sisaldus oli Kaugatuma piirkonnas madal, Kuressaare ja Kõiguste lahes oli toitainete hulk mõõdukas. 